\title{
Consumption junkies or sustainable consumers: considering the grocery shopping practices of those transitioning to retirement
}

S. Venn*, K. Burningham*†, I. Christie* and T. Jackson*

* Centre for Environmental Strategy, University of Surrey, Guildford, UK. $\dagger$ Department of Sociology, University of Surrey, Guildford, UK.

\section{Published in Ageing and Society}

Available on CJO 2015 doi:10.1017/S0144686X15000975

\begin{abstract}
The current generation of older people who are approaching or recently experiencing retirement form part of a unique generational habitus who have experienced a cultural shift into consumerism. These baby boomers are often portrayed as engaging in excessive levels of consumption which are counter to notions of sustainable living and to intergenerational harmony. This paper focuses on an exploration of the mechanisms underpinning the consumption patterns of baby boomers as they retire. We achieve this through an understanding of the everyday practices of grocery shopping which have the potential to give greater clarity to patterns of consumption than the more unusual or 'extraordinary' forms of consumption such as global travel.
\end{abstract}

In-depth interviews with 40 older men and women in four locations across England and Scotland were conducted at three points in time across the period of retirement.

We suggest that the grocery shopping practices of these older men and women were influenced by two factors (a) parental values and upbringing leading to the reification of thrift and frugality as virtues, alongside aspirations for self-actualisation such as undertaking global travel, and (b) the influence of household context, and caring roles on consumption choices. We conclude with some tentative observations concerning the implications of the ways baby boomers consume in terms of increasing calls for people to live in more sustainable ways.

\section{Keywords}

Ageing, retirement, baby boomers, consumption, grocery-shopping 


\section{Introduction}

Individuals are now being charged with making substantial changes to the way they consume on an everyday basis as a means of encouraging engagement with more sustainable lifestyles (Evans 2011, Hobson 2008, Connolly and Prothero 2008). The consumption practices of one group of individuals, the so-called baby boomers have come under particular scrutiny in academic writing, the press and social media (McCarthy 2013; Elkington, 2011; Willetts, 2010; Biggs et. al 2007) where they are regarded as currently engaging in unsustainable levels of consumption in comparison with other generations, and with little concern for the environment, for sustainability issues and for generativity (Haq, Brown and Hards 2010; Wright and Lund 200). In addition, their consumption choices and practices are expected to continue into retirement, as suggested by Gilleard and Higgs 'those who grew up spending freely earlier in life are more likely to continue to spend freely later in life' (2005: 153). Thus baby boomers are charged with being the 'selfish' or 'greedy' generation (Karisto 2007; Street and Crossman 2006) who are expected to continue engaging in self-actualizing lifestyles characterised by global travel and mass consumerism (Harkin and Huber 2004; Fairlie 1988; Haq et al. 2007; Karisto 2007; Willetts 2010).

Whilst these discourses abound, there are some, albeit less sensationally represented, counter discourses which present older people as proponents of thrift and the avoidance of waste (Hurd and Rohwedder 2006; Mansvelt 2010). Similarly, Breheny et al. highlight how older people are less likely to want what they cannot afford, and more likely to own fewer luxury items than younger people as they re-assess and adapt their preferences in later life (2014).

In this paper we seek to give greater clarity to the consumption practices of the baby boomers in light of the discourses that surround them. We aim to do this through an understanding of the reality of their grocery shopping practices. It is these particular practices which are part of everyday life and yet are most often embedded, invisible and taken for granted. As such they have greater potential for revealing retirees' patterns of consumption than the unusual and less frequent (Gronow and Warde 2001; Clarke et al. 2006). We commence by exploring the current discourses surrounding the consumption practices of the baby boomers, many of whom are experiencing or approaching retirement. We then move on to explore in more detail their more 'ordinary' grocery shopping practices and consider the implications of the transition to retirement on the performance of these practices. Finally, acknowledging Gabriel and Lang's claim that 'Western consumerism is facing and creating serious threat' 
and that 'these range from ecological crises such as climate change and resource shortage to financial and political uncertainties' we conclude with a consideration of some of the potential environmental implications of later life consumption (2006: vii).

\section{Baby boomers as consumers}

Gilleard and Higgs (2007) have suggested that the current generation of older people who are approaching retirement form part of a unique cultural shift into consumerism, with a distinct 'generational habitus'. This baby boom generation, that is those born between 1946 and 1964, grew up at a time when post war Britain was moving away from long periods of austerity, and had increasing access to higher levels of income through stable employment (Gilleard and Higgs, 2007; Higgs and Gilleard 2010; Higgs et al. 2009). The emergence of an expanding consumer market in the 1960s accompanied this increase in access to greater wealth and prompted a culture of consumption. At the same time state responsibility for later life declined so that older people were no longer seen as dependent on welfare, retirement was not necessarily a decline into poverty and older people were, and have been, regarded as being proponents of 'consumer sovereignty' characterised by choice and agency (Thane 2009; Giddens 1991; Trentmann 2009).

Therefore, as Higgs argues, baby boomers are 'marked out by lifestyles and subcultures that evolved during the emergence of a mass consumer society, located in their most concentrated form within the lifecourse of a particular birth cohort, powered by the logics of consumption' (Higgs 2010: 23, author's emphasis). Consequently, it is suggested, older people approaching retirement today are more likely to be active in all areas of life, physically, politically and as 'new age consumers' entering a 'dangerous territory of infinite desire" (Gilleard 1996: 495).

How much of this engagement with consumerism is entirely driven by individual agency is, however, open to debate as consideration needs to be given to policy agendas which emphasise the need for older people to manage their own later life trajectories. For example, recent 'active ageing' policy frameworks have emphasised the link between activity, health, independence and successful ageing (Walker 2002). Whilst the goal of 'active ageing' is to empower older people, it should also be noted that the origins of this framework were originally allied to aspirations about helping older people to continue as economically active producers and consumers for as long as possible and to mitigate against projected social and 
health costs (Bass, Caro and Chen 1993; Gilleard 1996, Gilleard and Higgs 2000, Jones et al. 2008). Additionally, in the UK pension reforms have been aimed at encouraging those approaching retirement to save for their later life through a number of different personal and occupational schemes. More recently, however, the introduction of 'pension freedoms' whereby those with defined pension contributions are able to cash in their 'pension pots' from the age of 55, have given rise to conjecture that, far from saving for their future, new retirees will be encouraged to 'blow their savings'(Price 2015; Peachey 2014).

All this would suggest, therefore, that consumption over time, and through the transition to retirement, would at least be consistent if not increasing, yet British households have actually demonstrated a fall in consumption at the time of retirement (Hurd and Rohwedder 2004; Lundberg, Startz and Stillman 2001). Hurd and Rohwedder suggest that this fall may be explained, to some extent, by an anticipated reduction in access to financial resources, a decrease in day to day expenses, an increase in the amount of time available to shop more efficiently and by swapping bought goods for home-made (Hurd and Rohwedder, 2004).

It has also been argued that this same cohort are not only known to adhere to parental values of resilience, thrift and frugality (Hamilton and Hamilton 2006), but also that rather than focus their spending on themselves, they divert their consumption practices to the family, which increasingly constitutes adult children, grandchildren and older relatives (Mansvelt 2010; Phillipson et al. 2008). This decline in consumption in households approaching and going through retirement therefore contradicts claims that the lifestyles of baby boomers are characterised by excessive consumption, and the implications this has for social justice agendas which foreground the adoption of sustainable lifestyles (Smith 2004; Wright and Lund 2000; Fairlie 1988).

In fact, not only is there uncertainty concerning the claims that the consumption practices of baby boomers are one of the major contributors to anthropogenic climate change, but there is also evidence to suggest that baby boomers are more caring about the environment than other generations (Kelly 2012). Research has suggested that baby boomers report high levels of environmental concern and behaviours (Phillipson et al. 2008) and are more likely to have higher levels of civic engagement through volunteering activities in retirement. The socialisation hypothesis in Inglehart's post-material values thesis suggests that adults' values reflect the things that were relatively scarce in their formative years (Inglehart 1981). Thus 
those brought up in the relative economic affluence of the post-war period were likely to grow up to hold post-material values, which include environmental concern. This theory can be used to help explain the rise of environmentalism in the late 1960s and early 1970s whereby a generation of children born in the relative economic security and stability of the post war years grew up to hold post-material values and to be active within the new social movements, of which environmentalism was one. Inglehart also suggests that these values do not change as people grow older, rather they are carried with them: 'one's basic values reflect the conditions that prevailed during one's pre-adult years' (Inglehart 1982: 881). As baby boomers grow older and move into retirement, therefore, it seems likely that far from ignoring their ecological responsibilities, they actually retain their environmental concerns and behaviours (Pakulski and Tranter, 2004; Huber and Skidmore 2003).

\section{Transitioning to retirement}

Whilst the baby boomer cohort covers a wide age range (50-68) many of them are currently making the transitioning to retirement. The significance of lifecourse transitions has been recently explored in a literature review by the New Economics Foundation (Thompson et al. 2010) who concluded that 'moments of change' such as retirement, are likely to lead to changes in a variety of aspects of everyday life such as travel, leisure consumption, energy use and purchase of consumer goods, all of which have environmental implications.

Retirement may be regarded as a nexus, a point at which self-identity is reconsidered as existing identities shift (for example, from worker to retiree), and the self becomes a 'reflexive project' (Giddens 1991). Lifestyles comprise, according to Giddens, an 'integrated set of practices' which 'give material form to a particular narrative of self-identity' (1991: 81) and which, together with decisions about broader considerations of the right way to live one's life, come together in the form of life politics. As such retirement is a time at which individuals may consciously reflect on the lifestyles they want, are able to have and which they feel they may have earned as a right following years of employment and selflessness when the focus has been on the wellbeing of other family members. Included in these reflections are considerations of potential future risks in the form of possible health problems or financial insecurity, all of which emphasise the need to consider the finitude of time available and how best to spend it (Goodwin and O'Connor 2014). 
The opportunities such potential for 'self-actualisation' in retirement have to offer has not been missed by marketing companies and advertisers as they have targeted retiring baby boomers as an emerging niche market for consumption in areas comprising for example, 'grey gap year' travelling, anti-ageing cosmetics, plastic surgery and as explorers of increasingly divergent food purchasing opportunities (Gunter 1998; Jones et al. 2008).

In considering the baby boomers' ways of consuming, the aims of this paper are to (a) examine the everyday grocery shopping practices of those transitioning to retirement, (b) explore the underlying factors which orientate retirees to their everyday consumption practices through the transition to retirement, and (c) explore the implications of (a) and (b) in terms of their relationship to ways of living sustainably.

\section{Study Design}

The data analysed in this paper are from a project which sought to provide an in-depth exploration of a range of issues relating to the way in which the everyday practices of people experiencing either the transition to first time parenthood or to retirement may become more or less sustainable (ELiCiT: Exploring lifestyles changes in transition, part of the Sustainable Lifestyles Research Group, SLRG) (Burningham et. al 2014). The data presented focus on those making the transition to retirement.

A practice based approach places practices at the heart of the model of social change rather than the individual (Spaargaren, 2003). For those adhering to practice theory 'understanding social change is in essence a matter of understanding how practices evolve, how they capture and lose us, their carriers' (Shove 2010: 1279). Thus the focus is on the practice itself rather than the individual - the source of changed behaviour lies in the practice, not the individual (Warde 2005: 140), and allows for an understanding of the influence of norms, conventions and expectations on the performance of a practice or practices. Yet, whilst practice approaches to sustainable consumption are often counterpoised to those which focus on individual circumstances, beliefs, motivations and choices (Shove 2010) we do not see them as necessarily incompatible and see benefit in combining insights from both. As Warde makes clear, there are manifest differences in how individuals and groups engage in the same practice which are: 'not solely a function of stratification by socio-demographic factors, relevant though that remains, nor simply a matter of the differential distribution of attitudes, interpretations and motivations' (2005: 147 emphasis added). Warde further highlights how 
'empirical evidence indicates differences between groups of people with regard to their understandings of a practice, the procedures they adopt and the values to which they aspire' (Warde: 139 emphasis added). We therefore present individuals' accounts of how they perform the practice(s) of grocery shopping, which allows for an exploration of the influence of social values, beliefs and social norms on practice.

Ten participants planning to retire in the near future were recruited from each of four locations ( $\mathrm{n}=40$ ), South London, Kent, Lancashire and Scotland. Reflecting the fluctuating status of the broader context of the recession in the global market and concerns surrounding financial security, nine of the retirees who had expected to have retired before the final interview had not done so, with some even increasing their current working hours or taking on an extra job. Analysis of the interviews of these participants has therefore been excluded from this paper, leaving a remainder of 13 female and 18 male participants $(n=31)$ in the analysis.

Each participant was invited to undertake three in-depth interviews in their own homes, at eight month intervals. The first interview took place prior to retirement, a second interview eight months following retirement and a final interview eight months later. Participants ranged in age from 48 to 72 , with an average age of 62 . All were white British, and were recruited from a range of socio-economic status, although difficulties in recruitment led to a majority of the participants presented here being from socio-economic groups A, B and C1 $(n=24)$ (see Table 1). Reflecting the current complex and fluid nature of household living arrangements, the majority of the participants were partnered and/or living in households with children or other family members $(n=27)$. Only 4 participants were living alone (all female).

Currently in the UK the age of eligibility for receipt of the state pension for women is increasing to equalise with men at age 65 by 2018, and thereafter increasing for both men and women to reach 66 by October 2020. Therefore at the time of data collection, many participants were not eligible to take up the state pension. In addition, they, and their partners where applicable, had varying access to personal and/or occupational pensions, as detailed in Table 1. 
Interviews were broadly developed around understanding participants' lifestyles with particular attention to aspects of change and continuity across the transition to retirement. Whilst an interview topic guide was used as a framework to ensure consistency across all interviews, participants were encouraged to talk freely and openly (Patton 2001). Questions during the interview focused on everyday practices deployed around themes such as what is important about their home, food purchase and consumption, modes of transport and leisure activities, families and social networks, and participants were asked to reflect on aspects of change about which they felt positive or negative. Participants were not recruited on the basis of their environmental beliefs, nor were questions concerning what might constitute a sustainable lifestyle asked until the final interview. This approach allowed us to focus on gaining an understanding of the participants' everyday practices, without any undue emphasis being placed on the sustainability or otherwise of these practices.

To protect the anonymity and confidentiality of the participants, pseudonyms have been used and the interview from which the quotation is taken is indicated in parentheses. All participants received a small honorarium in compensation for their time; confidentiality and anonymity was assured and ethical approval was granted by the University of Surrey. All interviews were fully transcribed and the software package NVivo10 was used to support a thematic analysis approach. For the purposes of this paper, emerging themes relating to grocery shopping were identified by reviewing participants' answers in both pre and posttransition interviews as to the how, when, where, and ways of shopping with a view to capturing continuity and change.

Insert Table 1 here

\section{Findings}

In seeking to address the points related to baby boomers' consumption practices in the Introduction, we will argue that two factors are most influential. Firstly we will demonstrate how the narratives of retirees revealed aspirations of 'self-actualization', in the form of desires to travel globally and consume widely. Yet their everyday grocery shopping practices were rooted in values which they observed had emanated from those of their parents' generation, resulting in the reification of 'thrift' and 'frugality' as virtues, but with varying consequences in terms of the environmental impact of their consumption practices. 
Secondly, we will stress the significance of household interactions, as they demonstrate aspects of caring roles and identities which are both implicit and complicit in influencing the everyday shopping practices of retirees.

\section{Aspirations to consume}

When talking to the participants about their hopes and expectations for retirement they revealed divergent narratives between a desire to explore the freedom of retirement as a 'time for me', which included an expected increase in consumption, alongside inherited principles of avoiding consumption and waste. Indeed, their aspirations for self-actualization in the form of new leisure interests and travel in retirement were very much redolent of the discourses portraying baby boomers as consumption ‘junkies'. Gail, for example, was hoping to travel as part of her 'grand scheme', and Veronica, who had already travelled considerably, planned to continue doing so in retirement:

So I think we'll just wait and see what happens. You know until we get so fed up that we'll go somewhere -that was in the grand scheme of things that we would start doing some more serious travelling. (Gail, Interview 2)

We were looking at and thinking about India again last night. We probably will go to India again, maybe next year, maybe the year after. I am desperate to go to Spain, I need to go to Spain. (Veronica, Interview 1)

Yet these 'extraordinary' consumption narratives were juxtaposed with detailed descriptions of their ordinary everyday grocery shopping practices, which were much more revealing of post-material values in the form of mandates to shop judiciously and to avoid consumption and waste, albeit not necessarily portrayed as for environmental reasons. Of note here is that considerations for personal future financial circumstances had little bearing on either their aspirations, or shopping practices. Participants were in receipt of different sources of income, ranging from no pension, state pension only, occupational pension only or both state and occupational pension (see Table 1). However, the majority had undertaken very little forward financial planning, and had little or no idea of how much disposable income they would have in retirement, as illustrated by Stella, a Social Worker, who was unclear about how much income from pensions she would receive: 'My finances are a bit up in the air, just 
muddled. As far as I know, I have a pension from the NHS, that's been coming in, and my old age pension' (Interview 2).

This very much resonates with Goodwin and O'Connor's work with largely working class participants who had also undertaken little forward financial planning and who also expressed aspirations to travel and undertake leisure activities in retirement (2014). Goodwin and O'Connor suggest this creation of an idealised retirement emanates from a desire to ameliorate the fears and anxieties associated with an unknown future and this may well be echoed by the participants in this study:

I want to do everything long haul before we're 70 because the insurance starts flying up and you may not have the energy to do that. (Terry, Interview 1)

Regardless of how much awareness participants did or did not have of their post-retirement income, for the majority aspirations to engage in 'extraordinary' consumption practices after retirement largely remained unfilled. Foreign holidays, resource intensive leisure activities and larger purchases such as a new car were still, for the most part, regarded as goals to be achieved at some point in the future 'I mean, I did have a plan to go travelling round the country and I haven't really done that.' (Stella, Interview 2).

This was partly a function of retirement being a more, long drawn out transition process than anticipated as retirees adjusted to their new routines and financial circumstances. But it was also a function of the many other lifecourse transitions that transect retirement, such as health problems, relationship changes, and demands from other household members. What did remain constant throughout the transition, however, were the ways in which their everyday grocery shopping practices were performed through the underpinning of values that emanate from their parents' generation.

Derek, like others, demonstrated this disparity between aspirations for self-actualising in retirement with an approach to everyday shopping which was embedded in thrift and frugality. Like several of the participants, he reflected in his first interview that his parents were of a different generation, with a different set of values to his own 'they had the generation of save, save, save, save, save and that's what they've done, and we are of the generation if you can go somewhere, go now' (Interview 3). Yet when discussing everyday 
shopping, Derek also described himself as a 'disciple of Martin Lewis, the Money Saving Expert', and his approach to everyday shopping was more aligned to that of his parents' generation, where not wasting money was the primary goal:

I'm a deal man. So I am the shopper.... in the [newspaper], if you put in your cards on a Saturday and a Sunday for so many weeks, you get a voucher. So my voucher's from Morrisons, Unless... I get one from Sainsbury's. So today, spend $£ 20$ at Sainsbury’s and I get $6 p$ off fuel. If I can save money any which way, and I'll do it for anybody that wants to listen because I know enough places to look for deals on virtually everything. (Derek, Interview 2).

Following retirement, Derek did manage to achieve some of his aspirations to travel, although not to the extent he had hoped for, and in spite of him believing he and his wife had a comfortable pension ('so there shouldn't be a problem') the narratives he used to describe his shopping continued to demonstrate a desire to avoid unnecessary spending and wastage ('we don't waste stuff.. that's the way we are'). Whilst aspirations which have broader consumption implications may have faltered for several of the participants following retirement, a focus on careful consumption for everyday shopping remained constant.

Participants' reflections on intergenerational differences in attitudes and approaches to choices surrounding consumption also included the younger generation. Kenneth, for example, reflected on the excessive consumerism of his children, 'kids are terrible consumers, they think nothing of spending money like [having] cake and coffee out' (Kenneth, Interview 2). Leach et al. regard this positioning as 'bridging' whereby babyboomers adopt a 'modified materialism' somewhere between parental frugality and materialist perspectives of younger people (2013: 110).

However, whilst the participants in this study did reflect some elements of 'bridging' their identities (between inherited parental values of frugality, the materialism of younger generations and aspirations to consume), their grocery shopping practices were most often operationalised in the form of parsimonious bargain shopping, or thrift, and frugality. Yet we need to be mindful here of the potential discrepancy between 'thrift' and 'frugality' and the implications of both of these in environmental terms. Evans has suggested that they both 
imply a reduction in consumption, and therefore may be regarded as ethical 'insofar as it can be seen as an effort to do 'good' or 'right' by future generations, vulnerable populations, nonhuman species and the environment itself' (2011: 551). Nonetheless there are differences in their conceptualisation. Frugality is defined as being 'moderate or sparing in the use of money, goods and resources with a particular emphasis on careful consumption and the avoidance of waste' (Evans 2011: 552). Frugality has moral connotations connected to the right way to live, which is evident in avoiding extravagance and even expenditure. Thrift, on the other hand, whilst implying a careful approach to shopping, essentially encompasses spending in order to save, which in turn may potentially release resources to spend elsewhere. Thrift behaviours, therefore, potentially have negative implications for sustainable lifestyles (Evans 2011) and present as an alternative feature of consumerism, albeit a long way from the 'excessive' consumerism that baby boomers are charged with, as we explore in more detail below.

\section{Thrifty shopping}

Jackson et al.'s (2006) research on consumer choice suggested that considerations of shopping 'between' stores were for convenience and accessibility, whereas shopping 'within' stores was for 'notions of value, price and quality' (Jackson et. al 2006: 48). Within our study we recognise that this also guided, to a large extent, how participants approached their grocery shopping practices prior to retirement. However, following retirement, the participants were uniquely placed in that with more time available, they were able to exercise increased choice in terms of where, when and how they shopped, albeit still within the constraints of which shops were available and where they were located. A relaxation of routines and structures which constrained everyday shopping practices meant that rather than having to fit a shopping trip in around other activities, as noted in Jackson et al.'s study, participants had even more opportunities to engage in thrifty shopping practices between as well as within shops. Betty knew she was saving more money than when she was working 'because I shop around' as a result of having more time:

I'll look for all the bargains all around town because I've got the time now, you see, which I never used to. I used to say oh, I don't go in them shops, but it was because I didn't have time, I just went and did me shopping, but no, I shop around now so I do save on things. (Betty, Interview 3). 
As a result of having more time to explore between shops, participants developed greater skills and knowledge about where to find the best bargains and developed a depth of knowledge about the different merits of supermarket chains in terms of prices and value for money, which often had to be renegotiated on a daily basis in order to react to changing market forces:

Interviewer: So you'll switch supermarkets according to where the best deal is? Derek: $\quad 95 \%$ is Morrisons because (a) it's convenient and, (b) I think it's cheaper than Waitrose which is down the road, it's relatively cheaper than Sainsbury's, it's not as cheap as Asda but it's [Asda] not as convenient. (Interview 2)

It varies, sometimes I'll go to Morrisons, sometimes I'll go to Lidl, sometimes I'll go to Tesco. Sainsbury's I go to. (Jerry, Interview 2)

Adrian, once retired, planned his day around 'chasing' bargains in different shops, whilst his wife was still working:

This morning, what I've done, I've taken her [wife] to work, I've gone to the Co-Op, and because the Co-Op's got a flyer, Utterly Butterly for a $£ 1$, Heinz tomato sauce is a $£ 1$, I've gone in there, spent about 3 or 4 quid. Then I've taken the dogs to the park on the way from the Co-Op on the way home, and then I've gone off to Lidl's and I bought sugar, bacon, because they're on the offers, and I've come back, so today I spent about $£ 9$ but I got bag loads. (Adrian, Interview 3)

For some participants, though, the desire to be 'thrifty' and take advantage of bargains led to shopping over and above immediate needs and even hoarding 'well if we have a nuclear war my friends know where to come' (Sally); 'I once had a cupboard full of toilet rolls because they were on a very good offer (laughter)' (Theresa). Being 'thrifty' can be the end goal of itself, as Miller explains 'For some the thrill is in the bargain and it almost doesn't matter how much one spends in order to achieve it' (1998: 61). Shopping in this way is more about demonstrating prowess and skill at shopping at the point of consumption, rather than for the pleasure of the goods purchased (Warde, 2005; Miller 1998). We would not wish to claim here knowledge about Sally and Theresa's ability to use all the goods they purchased, but we 
argue that when taking advantage of bulk buying offers of the same goods on several occasions, the reasons for the purchase are more related to the pleasure of short term monetary savings rather than the longer term benefits. Veronica, in this extract, demonstrates she is well aware of the market forces encouraging her to bulk buy, but still continues to do so:

I'm great on the three for two offers, all those things, I always do that, look for those, but that's I think partly it's as much thinking that you don't want to waste money basically. If you can get three of them for the price of two that's a better thing to do ... even though I know that some of those actually don't [save you money]... you know it's a good way to make you buy more and you sometimes don't actually need them. (Veronica, Interview 3)

Cooking practices also changed as more time became available in retirement. Those who engaged in bulk purchasing of food through shopping thriftily, also had more time to explore ways to preserve the food they had purchased, such as batch cooking, baking and freezing. For some, cooking transformed from being an everyday necessity to a leisure activity, involving learning new skills, or re-engagement with lost ones. Mary finds the 'luxury' of having more time following retirement had changed her cooking practices, and she shopped 'on a daily basis rather than weekly' to explore a range of different types of food available locally:

I have always, I suppose, been a good cook, but I don't know, I am not cooking cordon bleu meals, I am making a bigger effort about cooking, you know.... I try and move around different shops for different things, which people think is a bit of a waste of time, and I think probably if you are working it would be a waste of time, but if time to cook is a luxury you can afford then you can go to different shops for different things. (Mary, Interview2)

Miller et al. suggest, that these skills of thrifty shopping and careful cooking are at the heart of older peoples' core identity and life politics, and have 'surprisingly little to do with pragmatics and need, and is, rather a core strategy in the construction and maintenance of ideals and values' (Miller et al. 1999: 83). 
It is important to acknowledge two further points here; firstly, and as mentioned above and following Evans (2011), thrifty shopping implies saving to spend and it is possible that in light of retirees' stated aspirations for 'extraordinary' consumption in retirement, any savings resulting from thrifty shopping may have potentially been set aside for travelling or other purchases. However, whilst some of the retirees did do just that, many more also used their savings to support their children in a variety of ways, whether in large donations to help with house purchases or in smaller, everyday treats, which we explore in more detail below.

Secondly, we cannot ignore the influence of the material context within which shopping takes place, whereby supermarkets enable a 'buy one get one free' culture, a point Veronica above acknowledged. Supermarkets are also numerous in number, and frequently located out of town, which encouraged people to drive some distances to find the bargains they sought, all of which, of course, has further environmental considerations (Jackson 2006).

\section{Avoiding waste - being frugal}

Whilst 'thrifty' shopping involved some element of consumption, it would be unwise, in environmental terms at least, to refer to bulk buying, cooking and freezing of food without also paying attention to food waste. In terms of the participants in this study, it would seem more appropriate to regard their practice of avoidance of food wastage as a frugal practice, in that it comprised the best use of available resources without the need to purchase more.

In fact, participants talked of avoiding food waste in very similar terms to bargain shopping, in that they extolled the virtues of 'waste not, want not' inherited from their parents, by using up left over food, or recycling it elsewhere, such as garden compost. Rhys hated the idea of wasting food, 'I look at what is in the fridge in a morning before I go off to work and think, stir fry tonight, and that will use up anything, old peppers or anything that is in there just goes in the stir fry, never waste anything' (Interview 1). Sally and Andrew explained how their avoidance of any sort of waste was a result of their upbringing:

I mean, I think that post-war era - being post-war babies - that had a lot of influence on our parents and how they brought us up. You know, waste not, want not, was the main, sort of, phrase in our household, really, you know. (Sally, Interview 3) 
Save energy when you can - all the time. Try not to waste food - all the time. Got my dad's habit there, always leave an empty plate. (Andrew, Interview 3)

Therefore participants justified their 'frugal' avoidance of waste, as being rooted in their upbringing as their parents impressed on them the need to 'waste not, want not', and to save money. Environmental reasons were not a part of this justification, either advertently or inadvertently, as Kenneth put it 'I am mean, not green' (Interview 3) and Sally confirmed, 'Yeah, I suppose I do buy things in season. I don't think... things that are out of season are more expensive, aren't they?' (Interview 3).

What then are the implications of thrift and frugality in environmental terms? Shopping between shops for bargains may mean driving further, or it may also mean exploring local shops on foot. Bulk buying and hoarding similarly suggest excessive consumption, whereas the frugal use of the food purchased and the avoidance of waste have clear positive benefits in terms of living sustainably. As mentioned previously, pro-environmental attitudes and practices were not the drivers of grocery shopping practices for these participants, yet in striving to save money, avoid waste and shopping carefully they were, as Hitchings et al. (2013) argue, 'inadvertent environmentalists' or 'sustainable consumers', a point which is rarely if ever acknowledged in the critique of the consumption 'junkie' baby boomer.

Yet, as Miller (1998) and others acknowledge, shopping is rarely an individual practice, but rather more often undertaken within households, which has particular resonance for the baby boomer generation who are also unique in the extent of their role as intergenerational carers. Aspects of caring roles and identities were also found to impact on participants' everyday consumption practices, to which we now turn.

\section{Including the household context - caring roles and identities}

A further characteristic of the baby boomer generation is that they are also synonymous with being the 'sandwich generation', involved in intergenerational care of elderly, frail relatives, adult but still dependent children, and increasingly, also for grandchildren (Grundy and Henrietta 2006; Arber and Timonen 2012). DeVault's work on feeding the family highlighted how care and food preparation are intrinsically linked, and typically gendered, in that it is mostly regarded as women's work (DeVault 1994). Similarly, Miller (1998) has suggested that shopping is an 'act of love', most often, but not always, undertaken by women, who are 
constantly monitoring their family's food preferences. One manifestation of this is the 'treat', bought most often 'in the moment' (Miller 1998). Miller's study of the shopping practices of inhabitants of a street in London revealed that 'Almost any substantial shopping expedition incorporated both the concept and the practice of the treat' (1998: 40). However, the predominant concept of the 'treat' is that it is an indulgence, and as such is regarded as being additional to normal household shopping requirements.

Increasingly, retirees in the UK are becoming childcare providers for their grandchildren, usually on an informal, unpaid basis (Gray 2005). Looking after grandchildren often prompted the purchase of 'treats', as in Rhys who encouraged his granddaughter to try different foods by buying several kinds of the same product:

My granddaughter, she's got a taste after her dad and myself. .... I had her here for dinner a fortnight ago and I got three or four different salamis in for her [to try]....she will try anything, absolutely anything. (Interview 2)

With more time available, and as mentioned previously, more opportunities to travel between shops, further opportunities arose not only to explore the shops for bargains, but also to purchase unusual, or special items for a family member. When Jerry retired, he had taken over the grocery shopping from his wife who was still working, and whilst he took time to shop for bargains, he would also include in his shopping a 'treat' for her, which he acknowledged was in addition to their normal shop and which impacted on the significance of the money he saved:

I suppose to a degree we're saving a little bit because I'm getting bargains, but then I see something that I think, oh [wife] would like that, so I buy that which I wouldn't normally do or we wouldn't normally have done. (Jerry, Interview 2)

Considerations for long term financial security were also important in deciding how to spend money, with a view to saving for the future, but also with a view to having the ability to have 'little treats in one's older age' (Kenneth) when perhaps financial resources may be reduced. Saving for the future was not only done for personal reasons, but also, and contradicting rhetorical claims concerning the selfishness of baby boomers, for their children's' future. Veronica, shopped locally, and carefully, and monitored her everyday shopping expenses in 
order to save for holidays. Yet Veronica was also concerned for her adult children 'I can see you know that the future isn't rosy' (Interview 2). In spite of being financially secure, her continuing perceived parental role led her to be cautious in terms of going away on holiday, which she regarded as a significant treat, now that she and her husband relied on a pension in their retirement:

Sometimes my daughter says, 'Well why don't you spend your money on a holiday?' and I always say 'Well we'll have a holiday' but I couldn’t spend $£ 6,000$ on a holiday because I would just be thinking, 'oh my God if I gave that to [daughter] they could do this and that and the other with it'. (Veronica, Interview 2)

Even those who avoided spending too much on groceries may, on occasion, make an exception for a family member, and found pleasure in buying food items they knew their family would enjoy, such as when adult children returned home for a visit, or grandchildren were being looked after. This provided opportunities for indulging family members with foods not normally regarded as 'healthy':

We will have usually something unhealthy and so pizza, crisps, cheese. Those are the kind of things that do not get regularly bought because they would get regularly eaten. (Stella, Interview 2).

Many of the female retirees monitored their partners' diet and sought to feed them healthy foods, but exceptions could always be made for a treat:

But I'm not saying we don't have a treat now and again, but I've cut [husband's diet] back (laughter) a terrible amount. I've been worrying about him, you know, he's pretty good at home. He'll have his porridge and he's quite healthy at home, but the minute he's away... Now, that's alright if it's the odd treat now and again, but when it's every week, you know? So I'm just wanting him back into a normal routine and lifestyle. (Adele, Interview 2)

Treating was not only about the items being purchased, it was also about where those items were purchased. Participants often held specific alliances and loyalties to particular 
supermarket chains, as in those who shopped in Sainsbury's were not likely to shop in Tesco's, and vice versa. These alliances emerged partially from the aesthetics of the shops they visited, but also from participants' attachment to a social class they believed they belonged to, or aspired to belong to as part of their creation of 'cultural capital' and status procurement (Jackson et al. 2006; Bourdieu 1984), which was symbolically represented by a specific supermarket chain (Miller 2012). Waitrose for example was perceived as being geared towards wealthier customers, and offered good quality, but at a higher cost, whereas Lidl, a discount supermarket, was inexpensive, but of poorer quality. Participants often ordered their preference for where they shopped according to how well they believed the supermarket reflected their 'cultural capital':

I get called a snob because I won't shop at Lidl's (laughter). (Margaret, Interview 2)

For those whose alliances to supermarket chains were strong, and who did not normally 'shop around' for bargains, shopping at more exclusive and expensive shops than they would normally have gone to was regarded as a treat, for themselves as well as the person they were shopping for. Grace, for example, usually did her family shopping at Londis: 'We have got a Londis, they are quite cheap', but considered going to Marks and Spencer for a treat 'if I really fancy something nice to eat then I go up to Marks and Spencer's' (Interview 2). Shopping for others in more expensive supermarkets suggested an even greater sacrifice (in financial terms) but the reward, or treat, for the shopper outweighed the sacrifice as it meant they could purchase better quality food to feed their families. Treating in this way was also rationalised through aspirations for quality, and shops such as Waitrose and Marks and Spencer were synonymous with good quality and therefore could be justified alongside the desire to 'treat'. Peggy, for example, travelled a lot further than her local shops in order to buy better quality meat at Marks and Spencer for her husband:

Peggy: I mean we went to Marks and Spencer last week [further than local shops]. Interviewer: So how does that work in terms of things that you buy locally or things that you go further away for?

Peggy: Well quality I think. I mean I wouldn’t buy Tesco chicken. Sorry, if you're having Tesco chicken for your tea tonight. My son's a butcher, remember or was a 
butcher. But he used to say, 'Don't buy Tesco, mum, it's full of water and don't buy Asda and blah-blah-blah.' I suppose I would rather eat less and eat well ... (Peggy, Interview 3)

We have suggested that shopping within a household context, influenced by aspects of care and love, has the potential to elucidate further the rationales surrounding peoples' shopping practices, and more particularly decisions about shopping over and above the regular items purchased, or in the usual shops. Following Gregson et al. (2002) we would suggest that treating as a form of shopping practice takes more than one form. Including a treat in the shopping trolley for others is clearly influenced by desires to demonstrate love and care even, to an extent, potentially over and above desires to be both thrifty and/or frugal. Treats for oneself, either now or making provision for future treats, is a moment of 'extraordinary' consumption in that it goes against the normal mode of shopping thriftily or frugally, albeit not necessarily to the same degree as that attributed to baby boomers alleged consumption practices. Shopping in different spaces is a treat not just in terms of what is bought (as a treat for self or others) but also allows for shifting 'shopping identities' as participants explored ranges of supermarkets they did not usually identify with, and speaks to aspirations for selfactualisation in retirement. As William suggested 'We go to Waitrose now ...I think we're at a certain age when you want the nicer sort of stuff, we don't care if it costs a little bit more' (Interview 3).

Whilst we are not arguing that buying the occasional 'treat', or intermittent shopping at more expensive supermarkets has significant implications for sustainable lifestyles, we would propose that suggestions on how to encourage more sustainable shopping need to be mindful of these influencing factors.

\section{Lifecourse transitions to retirement: implications for sustainable lifestyles}

We have seen so far that the performance of grocery shopping practices may change through retirement as a result of having more time, yet the underpinning rationales for the modes of everyday shopping remain constant, that is being thrifty and frugal whenever possible, but exploring the treat on occasion.

However, it is notoriously difficult to assess the impact of these practices in sustainability terms (Jackson 2006). For example, walking to the shop is invariably more sustainable than 
driving, and driving for a weekly shop is more sustainable than driving each day for immediate necessities. In this paper, we make no attempt to endorse particular ways of shopping as sustainable (or not). We can, nevertheless, make some general observations about how shopping practices may be interpreted as more or less sustainable, even though the reason for change may be financially driven. Ellen, for example, bought less overall following retirement, 'we spend far less on the food', and 'will rarely choose meat' (Interview 2). Stella had more time in retirement to visit local farmers markets 'I think maybe perhaps it's changed a little bit, I shop more in markets than I used to. I think I am a bit more concerned about the price of things' (Interview 3 ).

However, bargain hunters, like Sally or Theresa who acknowledged that they purchased more than they could easily consume, or John, for example, who used the extra time he had in retirement to drive further to the shops, may be regarded as acting in an unsustainable way:

Interviewer: $\quad$ And are your shopping habits similar? I mean are you going to the same kinds of shops, or do you think you have changed that?

John: Similar, but perhaps more extensive. I am quite happy to drive further to get to Waitrose for example, or Sainsbury's rather than the local Tesco. Yes, I am quite happy to do that, I quite like it really. (Interview 2)

In addition to being able to make use of more time to shop for bargains, some participants were also able to (re)-acquaint themselves with local shops and engage in 'slow' shopping, that is appreciating locally produced and traditional food and which is also known to benefit the community (Scherger, Nazroo and Higgs 2010). Others were also likely to do less local shopping in retirement because they were buying a smaller amount overall 'I probably visit local shops a lot less, that's probably why I don't buy so much food, because I'm not going to shops for the sake of going to the shops' (Stuart, Interview 3). These reflections on how their shopping had changed since retirement show subtle alterations to modes of shopping, which may only have limited environmental implications, yet they are important in considering the overall consumption practices of retiring baby boomers, which may indeed strengthen the case for identifying them as (inadvertent) 'sustainable consumers' (Hitchings et al. 2013).

\section{Discussion and Conclusions}


The narratives of these men and women as they transition through retirement revealed a complex interconnectedness of factors which influence grocery shopping practices.

Changing access to time, moral codes surrounding careful consumption emanating from a life politics passed down by the previous generation, and shopping in a household context influenced the how, when and where of grocery shopping per se, and inevitably aspects of sustainable grocery shopping.

We have argued that those currently approaching retirement are unique in their generational habitus, growing up as they did in rapidly changing times, subject to opportunities to engage in lifestyles characterised by excessive consumerism (Gilleard and Higgs 2007). Yet, as evidenced above, we need to be cautious about labelling all baby boomers as 'consumption junkies' who have no regard for future generations. Firstly we have shown in this paper that on the one hand, and regardless of financial resources, many of the participants were expecting retirement to be a period of self-actualisation, which encompassed aspirations to travel and to consume, with all the negative implications this has for the environment. Yet, their everyday grocery shopping practices were anchored within traditional family values which reify thrift and frugality as virtues, although the consumption implications attached to notions of thrifty shopping need to be acknowledged. It is, therefore, perhaps more appropriate to consider some elements of baby boomers' shopping practices as sustainable, albeit, as Hitchings et al. suggest, unknowingly, or inadvertently (2013).

Secondly, we suggested that grocery shopping practices are not solely reliant on individual lifestyle choice but rather are associated with a caring identity, embedded within perceived household and social roles. As Jackson explains, the link between consumption and identity is 'related to wider structures of social interaction, especially those concerned with gender relations and the family, [and] with generational differences' (1999: 36).

Pebley (1998) suggested that an increasingly ageing population would have substantial impact on consumption patterns, which in turn would have implications for the environment, and predicted that this would be more significant as the baby boomer generation approached retirement. Echoing this prediction, Wright and Lund argued that 'identifying these consumption patterns and their impact on the environment will be valuable to developing programs and guidelines to minimize detrimental and irreversible ecological footprints' (2000: 238). Yet we advise caution here in reproducing the rhetoric that accompanies 
suggestions of retirees in engaging in 'damaging' consumption patterns, not only because this replicates, once again, the negative aspects which are so commonly associated with age and ageing, but also because our own research has shown that traditional values of frugality exist, or even override, indulgence at the expense of future generations and of the environment (Jackson, 1999). Nevertheless, further research still needs to be undertaken to obtain a clearer understanding of lifestyle choices and structural constraints invoked in patterns of consumption, and an approach to studying mundane consumption may bring to light those practices, such as grocery shopping, which are not clear cut in terms of their environmental impact.

We also need to be conscious of the heterogeneity of baby boomers, and their individual experiences of retirement, particularly as retirement is not the clearly defined 'moment in time' that it used to be (Thompson et al. 2010). For example, similar to Kim and Moen's research (2001), early indications from this study are that those who had recently retired were experiencing a 'honeymoon' period where the reduction of work stress, removal of structured routines, and access to more time were regarded by most as positive experiences, alongside an adjustment (for the most part) to a reduced income. All of this may change, however, as retirees move through the retirement process, experience multiple transitions, and (re)negotiate their everyday lives.

As Thompson et al (2010) have pointed out, there is a lack of evidence on the interaction between retirement and pro-environmental behaviours, and it has been equally difficult to identify potential, suitable, interventions to encourage such behaviours. There is clearly a need to explore the impact of the intersection of an ageing demographic with sustainability issues as both challenges escalate. However this would need to be mindful of avoiding the adoption of an approach that focuses solely on negative aspects of an increasingly ageing population. Whilst attention is being paid to the need to identify consumption patterns of baby boomers in policy terms, the focus seems to be on how they will consume health and social care, rather than on consumption which has environmental implications. However, there is clear potential within this cohort of retiring baby boomers to tap into their political radicalism and post-material values which have shaped their attitudes and values towards consumption and to join with younger generations to mitigate the negative connotations of what being a baby boomer might comprise. Policy could, for example, focus on the positive contributions older people can make to sustainable living through their interaction with local 
communities, engagement with volunteer organisations, and their roles as (largely unpaid) intergenerational carers in order to balance the equity between past, present and future generations (Wright and Lund, 2000). This might go some way to shifting the perception of retiring baby boomers as consumption 'junkies' towards highlighting their (inadvertent) 'sustainable consumption'. 


\section{References}

Arber, S. and Timonen, V. (Eds). 2012. Contemporary grandparenting: Changing Family Relationships in Global Contexts. Policy Press, Bristol.

Bass, S., Caro, F. and Chen, Y.-P. 1993. Achieving a productive ageing society. Auburn House, Westport, CT..

Biggs, S., Phillipson, C., Leach, R., Money, A. 2007. Baby boomers and adult ageing: issues for social and public policy. Quality in Ageing, 8, 3, 32-40.

Bourdieu, P. 1984. Distinction: A Social Critique of the Judgement of Taste. Routledge, Abingdon.

Breheny, M., Stephens, C., Henricksen, A., Stevenson, B., Carter, K. and Alpass, F. 2014. Measuring living standards of older people using Sen's capability approach: development and validation of the LSCAPE-24 (Living Standards Capabilities for Elders) and LSCAPE-6, Ageing and Society, Available on First View 20 October 2014..

Burningham, K., Venn, S., Christie, I., Jackson, T., Gatersleben, B. 2014. New motherhood: a moment of change in everyday shopping practices? Young Consumers. 15, 3, 211-226.

Clarke, I., Hallsworth, A., Jackson, P., de Kervenoael, R., Perez del Aguila, R., Kirkup, M., 2006. Retail restructuring and consumer choice 1 . Long-term local changes in consumer behaviour: Portsmouth, 1980 - 2002. Environment and Planning, 38, 1, 25-46.

Connolly, J. and Prothero, A. 2008. Green Consumption: Life-politics, risk and contradictions. Journal of Consumer Culture, 8, 1, 117-145.

DeVault, M. 1991. Feeding the Family: The social organization of caring as gendered work. University of Chicago Press, Chicago.

Elkington, J. 2011. Will Generation Zero clean up the Baby Boomers' environmental mess? http://www.guardian.co.uk/sustainable-business/sustainability-with-johnelkington/generation-zero-baby-boomers-environmental-mess. [Accessed 10 July 2013]

Evans, D. 2011. Thrifty, green or frugal: reflections on sustainable consumption in a changing economic climate. Geoforum, 42, 5, 550-57.

Fairlie, H. 1988. Talkin' 'bout my generation. New Republic, 798, 13, 19-22.

Gabriel, Y. and Lang, T. 2006. The Unmanageable Consumer. Sage Publications, London.

Giddens, A. 1991. Modernity and Self-Identity: Self and society in the Late Modern Age. Polity Press, Cambridge.

Gilleard, C. 1996. Consumption and identity in later life: towards a cultural gerontology. Ageing and Society, 16, 4, 489-98.

Gilleard, C. and Higgs, P. 2000. Cultures of ageing: self, citizen and the body. Pearson Education, London.

Gilleard, C. and Higgs, P. 2005. Contexts of Ageing: Class, Cohort and Community,

Polity Press, Cambridge.

Gilleard, C. and Higgs, P. 2007. The Third Age and the Baby Boomers: Two approaches to the social structuring of later life. International Journal of Ageing and Later Life, 2, 2, 13-30.

Goodwin, J. and O'Connor, H. 2014. Notions of fantasy and reality in the adjustment to retirement, Ageing and Society, 34, 4, 569-89. 
Gregson, N., Crewe, L. and Brooks, K. 2002. Shopping, space and practice. Environment and Planning D: Society and Space, 20, 5, 597-617.

Gray, A. 2005. The changing availability of grandparents and its implications for childcare policy in the UK. Journal of Social Policy, 34, 4, 557-77

Gronow, J. and Warde, A. (eds). 2001. Ordinary Consumption. Routledge, London.

Grundy, E. and Henrietta, J. 2006. Between elderly parents and adult children: a new look at the intergenerational care provided by the sandwich generation. Ageing and. Society, 26, 5 , 707-7.

Gunter, B. 1998. Understanding the Older Consumer: the Grey Market. Routledge, New York.

Hamilton, M. and Hamilton, C. 2006. Baby boomers and retirement: dreams, fears and anxieties. Discussion Paper 89. The Australia Institute, Canberra, Australia.

Haq, G., Minx, J., Whitelegg, J. and Owen, A. 2007. Greening the greys: climate change and the over 50s. Stockholm Environment Institute, University of York. Available online at http://www.sei-

international.org/mediamanager/documents/Publications/Future/ClimateChangeandOver50s.p df. [Accessed 22 May 2013].

Haq, G., Brown, D. and Hards, S. 2010. Older people and climate change: the case for better engagement. Stockholm environment Institute, Project Report - 2010. Available online at http://www.sei-international.org/mediamanager/documents/Publications/Climate-mitigationadaptation/ -old people and climate change100826lowres.pdf. [Accessed 2 August 2012].

Harkin, J. and Huber, J. 2004. Eternal youths. How the baby boomers are having their time again. Demos, Hendy Banks, London.

Higgs, P. 2010. Consumption in later life: understanding older age through the prism of consumerism, presentation to CARDI (Centre for Ageing Research and Development in Ireland), 20 May 2010,

http://www.cardi.ie/userfiles/Paul\%20Higgs\%20Seminar\%2019th\%20May\%202010\%20(2). pdf. [Accessed January 2013].

Higgs, P. and Gilleard, C. 2010. Generational conflict, consumption and the ageing welfare state in the United Kingdom. Ageing and Society, 30, 8, 1439-1451.

Higgs, P.F., Hyde, M., Gilleard, C.J., Victor, C.R., Wiggins, R.D., and Jones, I.R. 2009. From passive to active consumers? Later life consumption in the UK from 19682005. Sociological Review, 57, 1, 102-124.

Hitchings, R., Collins, R., and Day, R. 2013. Inadvertent environmentalism and the actionvalue opportunity: reflections from studies at both ends of the generational spectrum. Local Environment, 20, 3, 369-385.

Hobson, K. 2008. Reasons to be Cheerful: Thinking Sustainably in a (Climate) Changing World. Geography Compass, 2, 1, 199-214.

Huber, P. and Skidmore, J. 2003. The new old: why baby boomers won't be pensioned off. Demos, London.

Hurd, M. and Rohwedder, S. 2004. The retirement-consumption puzzle: anticipated and actual declines in spending at retirement. Working Paper WP2004-069, University of Michigan Retirement Research Center, Ann Arbor, Michigan, U.S.A. 
Hurd, M.D. and Rohwedder, S. 2006. Some answers to the retirement-consumption puzzle. NBER Working Paper Series, 12057. National Bureau of Economic Research, Cambridge, Mass.

Inglehart, R. 1981. Postmaterialism in an environment of insecurity. The American Political Science Review, 75, 4, 880-900.

Jackson, P. 1999. Consumption and identity: a cultural politics of shopping. European Planning Studies, 7, 1, 25-39.

Jackson, T. 2006. Introduction. In Jackson, T. (ed.) Earthscan Reader in Sustainable Consumption. Earthscan, London, Chapter 1, 1-25.

Jackson, P. Perez del Aguila, R., Clarke, I., Hallsworth, A., de Kervenoael, R., and Kirkup, M. 2006. Retail restructuring and consumer choice 2. Understanding consumer choice at the household level. Environment and Planning A, 38, 1, 47-67.

Jones, I.R., Hyde, M., Victor, C.R., Wiggins, R.D., Gilleard, C. and Higgs, P. 2008. Ageing in a Consumer Society: From Passive to Active Consumption in Britain. The Policy Press, Bristol.

Karisto, A. 2007. Finnish Baby Boomers and the Emergence of the Third Age.

International Journal of Ageing and Later Life, 2, 2, 91-108.

Kelly, K. 2012. http://www.environmentalleader.com/2012/02/29/study-baby-boomersbelieve-in-sustainable-principles-and-will-pay-for-them/. [Accessed 10 July 2013]

Kim, J.E. and Moen, P. 2001. Retirement transitions, gender and psychological well-being. The Journals of Gerontology: Series B, 57, 3, 212-22.

Leach, R.M., Phillipson, C., Biggs, S., Money, A. 2013. Baby Boomers, consumption and social change: The bridging generation? International Review of Sociology, 23, 1, 104-122.

Lundberg, S., Startz, R. and Stillman, S. 2001. The Retirement-Consumption Puzzle: A marital bargaining approach. Labour and Population Program, Working Paper Series 01-04, RAND Corporation, Santa Monica, California, U.S.A.

Mansvelt, J. 2010. Learning through consumption: placing ageing through the lifecourse, In Blatterer, H. and Glahn, J. (eds) Times of our Live: Making sense of Growing Up and Growing Old, Probing the Boundaries, Oxford. Available online at http://www.interdisciplinary.net/probing-the-boundaries/making-sense-of/life-cycles/ [Accessed 20 August 2015].

McCarthy, M. 2013.

http://www.independent.co.uk/environment/nature/nature_studies/nature-studies-the-life-thatdisappeared-while-babyboomers-had-their-fun-8636316.html. [Accessed 24 April 2013]

Miller, D. 1998. A Theory of Shopping. Cornell University Press, Ithaca, New York.

Miller, D., Jackson, P., Thrift, N., Holbrook, B. and Rowlands, M. 1999. Shopping, place and identity, Routledge, Abingdon.

Miller, D. 2012. Consumption and its Consequences. Polity Press, Cambridge.

Pakulski, J. and Tranter, B. 2004. Environmentalism and social differentiation: A paper in memory of Steve Crook. Journal of Sociology, 40, 3, 222-259.

Patton, M.Q. 2001. Qualitative Research and Evaluation Methods $3^{\text {rd }}$ Edition. Sage Publications, London. 
Peachey, K. 2014. Pension Reform: 10 hidden consequences, $B B C$ News website, http://www.bbc.co.uk/news/business-26666103. [Accessed 20 April 2015].

Pebley, A.R. 1998. Demography and the environment. Demography, 35, 4, 377-89.

Phillipson, C., Leach, R., Money, A. and Biggs, S. 2008. Social and cultural constructions of ageing: the case of the Baby Boomers. Sociological Research Online, 13, 3, http://www.socresonline.org.uk/13/3/5.html. [Accessed 22 May 2013].

Price, D. 2015. The Incoherence Now Underlying UK Pensions Policy,

https://gerontologyuk.wordpress.com/2015/03/16/the-incoherence-now-underlying-ukpensions-policy/ [Accessed 14 April 2015].

Rose, D. and O'Reilly, K. Eds 1997. Constructing Classes: Towards a New Social Classification for the UK. ESRC/Office for National Statistics, Swindon,

Scherger, S., Nazroo, J. and Higgs, P. 2011. Leisure activities and retirement: do structures of inequality change in old age? Ageing and Society, 31, 1, 146-72.

Shove, E. 2010. Beyond the ABC: climate change policy and theories of social change, Environment and Planning A, 42, 6, 1273-85.

Smith, S. 2004. Can the retirement consumption puzzle be resolved? Evidence from UK panel data WP04/07, The Institute for Fiscal Studies, London, UK.

Spaargaren, G. 2003. Sustainable Consumption: A Theoretical and Environmental Policy Perspective. Society \& Natural Resources: An International Journal, 16, 8, 687-701.

Street, D. and Crossman, J.S. 2006. Social Spending Preferences and the Elderly, Social Problems, 53, 1, 75-96.

Thane, P. 2009. Old Age, Consumption, and Change over time. In Rees Jones, I., Higgs, P. and Ekerdt, D.J. (eds) Consumption and Generational Change: The Rise of Consumer Lifestyles. Transaction Publishers, New Brunswick.

Thompson, S., Michaelson, J., Abdallah, s., Johnson, V., Morris, D., Riley, K. and Simms, A. 2010. 'Moments of change' as opportunities for influencing behaviour: a report to the Department for Environment, Food and rural Affairs. Nef (the new economics foundation). Defra, London.

Trentmann, F. 2009. Foreword. In Rees Jones, I., Higgs, P. and Ekerdt, D.J. (eds), Consumption and Generational Change: The Rise of Consumer Lifestyles. Transaction Publishers, New Brunswick, 1-20.

Walker, A. 2002 A strategy for active ageing. International Social Security Review, 5, 5, 121-39.

Warde, A. 2005. Consumption and theories of practice. Journal of Consumer Culture, 5, 2, $131-153$

Willetts, D. 2010. The Pinch: How the baby boomers took their children's future and why they should give it back. Atlantic Books, London.

Wright, S.D. and Lund, D.A. 2000. Gray and green?: Stewardship and sustainability in an aging society. Journal of Aging Studies, 14, 3 229-49. 


\begin{tabular}{|l|c|c|c|c|c|}
\hline & $\begin{array}{c}\text { No State } \\
\text { or } \\
\text { Occupatio } \\
\text { nal } \\
\text { Pension }\end{array}$ & $\begin{array}{c}\text { In receipt of } \\
\text { State Pension } \\
\text { only }\end{array}$ & $\begin{array}{c}\text { In receipt of } \\
\text { Occupational } \\
\text { Pension only }\end{array}$ & $\begin{array}{c}\text { In receipt of } \\
\text { both State and } \\
\text { Occupational } \\
\text { Pension }\end{array}$ & Total \\
\hline $\begin{array}{l}\text { *Socio-economic } \\
\text { group 1 (A, B, } \\
\text { C1) }\end{array}$ & 1 & 3 & 14 & 6 & $\mathbf{2 4}$ \\
\hline $\begin{array}{l}\text { Socio-economic } \\
\text { group 2 } \\
\text { (C2, D, E) }\end{array}$ & 0 & 3 & 1 & 3 & $\mathbf{7}$ \\
\hline Total & $\mathbf{1}$ & $\mathbf{6}$ & $\mathbf{1 5}$ & $\mathbf{9}$ & $\mathbf{3 1}$ \\
\hline
\end{tabular}

Table 1: $\quad$ Participants' Pension Status at time of final interview by socio-economic group*

*The two socio economic groups referred to and used in the UK are based on the occupation of the head of the household and broadly comprise:

Group 1: $A=$ Professionals and senior managers, $B=$ middle managers, $\mathrm{C} 1=$ junior managers - all of which are non-manual.

Group 2: $\mathrm{C} 2$ = skilled manual workers, $\mathrm{D}=$ semi or unskilled, or trainees, and $\mathrm{E}=$ those dependent on state benefits, long term unemployed or casual workers. (Rose and O'Reilly, 1997) 